\title{
Correction to: The role of oral co- trimoxazole in treating Nocardia farcinica keratitis: a case report
}

Neharika Sharma ${ }^{1 *}$ and Stephen O'Hagan ${ }^{1,2}$

\section{Correction}

This article [1] was unintentionally published twice in this journal, by the same authors.

The following [1] should be considered the version of record and used for citation purposes: "Neharika Sharma and Stephen O'Hagan, The role of oral co-trimoxazole in treating Nocardia farcinica keratitis: a case report. Journal of Ophthalmic Inflammation and Infection (2016) 6:21 DOI 10.1186/s12348-016-0087-y".

The duplicate [2]: "Neharika Sharma and Stephen O'Hagan, The role of oral co-trimoxazole in treating Nocardia farcinica keratitis: a case report. Journal of Ophthalmic Inflammation and Infection (2016) 6:23 DOI 10.1186/s12348-016-0091-2" is to be ignored.

BioMed Central apologizes to the readers of the journal for not detecting the duplication during the publication process.

\section{Author details}

${ }^{1}$ Cairns Base Hospital, 165 The Esplanade, Cairns, QLD, Australia. ${ }^{2}$ James Cook University, 1 James Cook Drive, Townsville City, QLD, Australia.

Received: 21 December 2017 Accepted: 21 December 2017

Published online: 08 January 2018

\section{References}

1. Sharma N, O'Hagan S (2016) The role of oral co-trimoxazole in treating

Nocardia farcinica keratitis: a case report. J Ophthalmic Inflamm Infect 6:21. https://doi.org/10.1186/s12348-016-0087-y

2. Sharma N, O'Hagan S (2016) The role of oral co-trimoxazole in treating Nocardia farcinica keratitis: a case report. J Ophthalmic Inflamm Infect 6:23. https://doi.org/10.1186/s12348-016-0091-2

\footnotetext{
* Correspondence: sharma.neharika86@gmail.com

${ }^{1}$ Cairns Base Hospital, 165 The Esplanade, Cairns, QLD, Australia

Full list of author information is available at the end of the article
} 